This is the accepted version of the following article:

Nunan, D. and Di Domenico, M. (accepted 2018), 'Theorizing Piratical Innovation: Regulatory Illegitimacy and Firm Growth’ Journal of Small Business Management

\title{
Authors:
}

Dr. Daniel Nunan, Birkbeck, University of London, UK.

Professor MariaLaura Di Domenico, Surrey Business School, University of Surrey, UK. 


\section{Theorizing Piratical Innovation: Regulatory Illegitimacy and Firm Growth}

This article examines the growing phenomenon of firms in 'winner takes all' markets which adopt business models that prioritize exceptional levels of growth over other financial metrics. Often this growth results in firms breaking with regulatory norms, despite regulatory legitimacy being theorized as essential for resource acquisition in small firms. The article explores this apparent paradox. We propose piratical innovation as a firm level process built upon disrupting regulatory norms in a way that avoids negative legitimacy judgments. Extending labelling theory, we develop a conceptual model where piratical innovation blends a range of symbolic and substantive actions to enable these firms to maintain legitimacy amongst stakeholders, even when growth is underpinned by illegitimate acts. We conclude by considering the wider applicability of piratical innovation as a model for small firm growth, and the consequences for other firms which must compete against such innovations.

\section{Keywords:}

firm growth; labelling contest; piratical innovation; regulatory illegitimacy. 


\section{Introduction}

A common theme in the entrepreneurship literature is that successfully growing a new firm is difficult and attempts often fail (Klepper 2002; Coad et al. 2013). As a result, new firms put a great deal of effort into generating the legitimacy needed to survive through undertaking activities that are socially and institutionally acceptable (Ashforth and Gibbs 1990). One emerging aspect of entrepreneurship involves high-growth business models associated with the pursuit of "winner takes all' markets (Schoonbeek 2001). In these markets, network effects result in only the largest firms being able to sustain profitability (Schilling 2002), leaving firms constrained not by capital (van Stel et al., 2007) but by the speed at which they can grow. Whilst popularized by firms in the sharing-economy, such as Uber in transportation and Airbnb in property rental, these business models are embraced by small businesses due to their status amongst current and aspiring entrepreneurs (Mikhalkina and Cabantous 2015). We suggest that understanding this phenomenon is important for two reasons. Firstly, for small firms pursuing a growth strategy, adopting these business models can be an attractive proposition. Secondly, whilst many firms are not focused on rapid growth (Churchill and Lewis 1983; Kirchoff and Phillips, 1988), the presence of firms with high growth strategies can affect all firms in a sector.

The argument of this paper is that in order to achieve the rapid growth required to succeed in winner takes all markets, firms adopt strategies that create the risk of regulatory illegitimacy. Typically, when dealing with illegitimate behavior, management focus is on decoupling the legitimate structures of the firm from any illegitimate actions. For example, a firm facing a public relations disaster may use communication strategies and PR to focus attention away from any negative activities by the firm (Elsbach and Sutton 1992). By contrast, this paper's focus is on firms that adopt growth strategies which generate negative legitimacy judgments, and the actions they adopt to mitigate the impact of these judgements. As legitimacy has been characterized as an asset, we seek to answer the question: Why do some new ventures succeed despite pursuing strategies that generate negative 
legitimacy judgments amongst stakeholders? As such, we seek to address the call for greater understanding into the processes that drive small firm growth (Wright \& Stigliani 2012). Building upon labelling theory, we characterize these forms of illegitimate behavior as an innovation strategy. Rather than a focus on innovation around products and services, the innovation comes in the form of the ability to create opportunities from regulatory arbitrage. We label this process as piratical innovation, reflecting both the risks involved in this approach and the complexity in maintaining stakeholder engagement, given the challenges and possible liabilities of illegitimacy that the firm must face. We develop research propositions and put forward a new model of the concept of piratical innovation as a firm-level process to protect legitimacy through the skillful use of symbolic management to manipulate labels applied by stakeholders to substantive management actions. We consider the applicability of piratical innovation as a growth strategy for small businesses as well as the response mechanisms for SMEs which must compete against firms adopting such strategies.

\section{Legitimacy and Entrepreneurship}

A legitimate firm is one that can be described as being perceived to pursue acceptable goals in a socially acceptable manner (Ashforth and Gibbs 1990). Legitimacy has long been characterized as a means of enhancing the chances of firm survival, and therefore as an important variable that managers can manipulate to improve organizational outcomes (Suchman 1995; Deephouse and Suchman 2008). One way this is done is through influencing the way that resources are allocated between organizations (Stern et al. 1979), with "legitimate" firms being better positioned to compete for these resources. In the context of the various liabilities that SMEs face, such as newness (Stinchcombe 1965), smallness (Aldrich and Auster 1986), or adolescence (Bruederl and Schuessler 1990), management strategies to acquire legitimacy play an important role in helping small firms grow. As institutional expectations matter to firms, the threat of being denied legitimate standing within an industry can be an effective tool through which to ensure compliance with institutional norms (Zuckerman 1999). 
In return, legitimacy provides several important benefits for new ventures. When faced with situations of uncertainty social actors refer back to the prescribed "stock of scripts, rules, norms, values, and models in order to proceed" (Zimmerman and Zeitz, 2002, p. 417). Thus, the pursuit of activities that are likely to foster legitimacy, whilst available at low financial and operational cost, is common within new ventures. By acquiring legitimacy, a firm can more easily signal its desirability to those who possess resources and be perceived as a lower risk (Muzyka et al. 1996; Zimmerman and Zeitz 2002). Conversely, when firms lack legitimacy, or take actions that result in a loss of legitimacy, they will receive less support from their stakeholders, less access to resources and growth opportunities and, ultimately, increase their chances of failing (Elsbach 2003; Pfarrer et al. 2008). Research into these "low legitimacy" contexts has focused on either the steps that firms can take to recover any lost legitimacy (Pfarrer et al. 2008; Vergne 2012) or discussion of legitimacy in organizations that operate business models that are effectively illegal (Reuber and Fischer 2010). For all these reasons, legitimacy has been characterized as a positive phenomenon for small firms, and activity aimed at building legitimacy as a desirable focus of management effort.

\section{Gaining and Protecting Legitimacy in Small Firms}

The pursuit of legitimacy by small firms can be understood from two perspectives: that of firms which have legitimacy, and that of those which seek more of it. For those lacking legitimacy, research explores the steps they can take to create and build influence within their industry (Zimmerman and Zeitz 2002). These steps involve conformance within existing practices, selecting of a favorable environment, or manipulation of the environment to generate new forms of legitimacy (Suchman 1995). A second stream of research addresses firms which have some legitimacy but wish to make better use of it. For example, firms that wish to emphasize their environmental credentials through "greenwashing" (Walker and Wan 2012). In addition to these two perspectives, we can add those firms which have lost legitimacy due to transgressions or cannot build it due to forms of stigma associated with the industry in which they operate (Hudson and Okhuysen 2009). Maintaining legitimacy can be 
particularly challenging where legitimacy is built upon expectations that firms ultimately deviate from, when addressing the twists and turns of decision-making faced by small firms (Garud et al. 2014).

As a result of these factors, the pursuit and maintenance of legitimacy has become a core part of management activity within firms seeking growth. One approach to legitimation characterized as particularly effective is compliance with institutional pressures from regulators, professional or trade bodies, which drive the adoption of prevailing practices to demonstrate social fitness (Tan et al. 2013). Within the context of the loose coupling between institutional and competitive isomorphism, failure to adopt institutional norms can have a major impact on stakeholder perceptions of legitimacy. In other words, by acquiring legitimacy through adopting institutional norms, firms must differentiate and innovate in the competitive arenas around products and services. From the perspective of a customer, by selecting firms that have adopted the institutional norms of more established firms, the risks associated with purchasing a new or unfamiliar product or service can be reduced (Zott and Huy 2007). Furthermore, by gaining institutional legitimacy amongst larger peers, a firm can share in any regulatory or other advantages that might apply to an industry as a whole. Whilst the positive benefits of legitimacy have been well explored in the literature, there has been less discussion of potential costs where entrepreneurs may face conflicting expectations around the need to conform (Stringfellow et al. 2013) and also innovate by standing-out (De Clercq and Voronov 2009). The successful pursuit of legitimacy, as typically characterized, requires not only mimicking institutional norms but complying with them. As such, legitimation can be characterized as a form of action that creates isomorphic pressures upon organizations. This cuts across a central theme of the innovation literature: the oftencontradictory pressures both to conform and to innovate (Deephouse 1999).

\section{Regulatory Legitimacy in 'Winner Takes All' Markets}

The question of why some firms grow but others do not forms an important stream of research within the small business literature (Storey and Greene 2010; Coad et al. 2013; Hansen and Hamilton 2011; Rasmussen et al. 2016). Areas of focus include the relationship between firm growth and 
profitability (Senderovitz et al. 2016), entrepreneurs' personal values (Churchill and Lewis 1983; Tomczyk et al. 2013) and vertical coopetition (Lechner et al. 2016). Approaches to research into growth have considered both lifecycle approaches that consider various stages of firm growth and links between specific firm characteristics and growth (Merz et al. 1994). Underlying these perspectives on growth in small firms is the idea that the pursuit of growth, and the rate at which firms grow, is a decision that is driven both by the market and also by the resources available to SMEs (van Stel et al. 2007).

The concept of "winner takes all markets" has featured widely in both the economics and management literature (Schoonbeek 2001); and there are many kinds of markets, such as those which are capital intensive or have high customer acquisition costs, where being the first to establish a dominant position in a market can provide significant effects. In this paper, we use the term in its contemporary sense, where "winner takes all" has been used to describe, more widely in the context of high-growth firms, those that are often part of the sharing economy (Malik 2015). Here, the use of the phrase "winner takes all" may be considered less a description of a market characteristic than a statement of corporate intent: If a firm can put itself in a position to be a winner then it can take, or capture, all of a market. With such definitions, the range of markets that could be considered suitable is much broader, as market selection is defined by firm level rather than industry level characteristics, not least the availability of capital to enable growth.

Much of the popularity behind the idea of these forms of business has come from awareness of "unicorn" ventures, a term typically used to refer to privately held firms that have received a notional valuation of at least US\$1 billion from their investors (Mchawrab 2016). These valuations, often applied to firms that are small by conventional financial or sizing metrics, are based upon rates of growth and perception of opportunities for shareholder value creation once they dominate markets (Mali 2015). Many of the most well-funded and high-profile "unicorn" ventures, including Uber, Lyft, Airbnb or Zenefits, have been characterized by the pursuit of growth whilst running substantial 
operational losses during these growth phases. Whilst these companies are atypical cases their success, and business models, have themselves become popular and more widely adopted by a range of smallerfirms (Mikhalkina and Cabantous 2015). The emergence of new technologies has also played an important role in the ability of firms to "win" in such markets, with the always-on and ubiquitous nature of the internet enabling subsequent network effects, allowing the creation of business models designed to maximize firm growth (Malik 2015). In these industries, for successful firms, network externalities lead to a single technology standard which locks out competitor firms (Schilling 2002). The impact of these firms can be seen not just in their size, but in the size of the networks that they enable. For example, it is estimated that more than 25 million individuals in Europe and North America leverage these kinds of digital platforms to generate income through the 'sharing economy' (Manyika et al. 2016), a number that is growing quickly. As advantages gained early can grow exponentially, this "extreme path dependency" (Schilling 2002, p. 387) creates intense pressure to pursue growth at all costs. We suggest that what is notable about this phenomenon is not that growth is being pursued, but the way in which firms adopt strategies that disrupt, or defy, existing regulatory norms in order to make such growth possible.

Why would some firms pursue this approach, given the link between regulatory legitimacy and growth (Zimmerman and Zeitz 2002)? In theoretical terms, regulatory legitimacy can be viewed as a mechanism that binds firms to various regulatory or legal norms. If firms can identify ways to subvert such norms without generating negative stakeholder judgements of the firm, they could gain significant competitive advantage. An advantage built on a purely regulatory basis could be leveraged at the same time through more limited application of capital and created through product innovation. For example, whilst Uber's high valuation is often attributed to its attempts to develop a future service based on selfdriving cars, it is the ability to bypass policies and regulations relating to operation of taxis and private hire services that has delivered growth (Davies 2017). Competitive advantages can be sustained due to reluctance amongst competitor firms to copy this behavior, for fear of losing legitimacy themselves. 
This is because undertaking behavior that could result in the loss of regulatory legitimacy is not without significant levels of risk. These risks include the challenges around avoiding regulatory or legal sanctions, difficulties in maintaining relationships with stakeholders, and building up a customer base built on a competitive advantage not underpinned by a product or service innovation (Goodwin 2017).

For many small firms, the risks involved in adopting such strategies will be too high. Yet, for firms pursuing very high levels of growth, and possessing the necessary capital to do so, potential opportunities gained by regulatory advantage may outweigh risks. Advantages are most available to firms with access to significant financial capital, which for example can be applied to price reductions or other forms of financial incentive. In turn, this can change market dynamics and cause challenges to other small firms that are competing and must develop effective response strategies. We discuss later on the consequences for competitor firms, and the range of strategic responses. We suggest that such subversion of institutional norms can lead to growth that is both faster and more sustained than through more traditional forms of capital allocation. Before we move on to consider how such complex and risky approaches might be implemented by firms, we first discuss the basis of our arguments in relation to the concept of piratical innovation.

\section{Conceptualizing the Pirate}

The use of the word "piratical" in this paper emerges from the widespread association of piracy within modern society as a rejection of institutional norms. Conceptually, pirates exist in a liminal space between ethical and unethical, both hero and villain (Smith 1980), with increasing understanding that piratical behavior can be both constructive and a source of innovation (Kaivo-oja 2014; Jemielniak 2014). The "dismoralisation" of piracy (Chaboud 2014; Roth 2014a) has enabled allusions to piratical behavior to become a part of entrepreneurial culture. Perhaps the best-known example is its use within Apple with Steve Jobs' famous quote "It's better to be a pirate than join the navy", forming an integral part of Apple's history and identity (Reisenger 2016). Its use reflects a desire to maintain a culture that 
preserves some of the rebellious and anti-bureaucratic capabilities perceived to have been a driver of innovation when Apple was a smaller firm.

I think the "pirates" remark addressed the feeling among some of the earlier team members that the Mac group was getting too large and bureaucratic. We had started out as a rebellious skunkworks, much like Apple itself, and Steve [Jobs] wanted us to preserve our original spirit even as we were growing more like the Navy every day. (Hertzfeld 1983)

In the case of Apple, the use of the pirate metaphor, accompanied by displaying a skull and crossbones flag in the office (Hertzfeld 1983; Reisenger 2016), has its origins in the traditional concept of maritime piracy rooted in the $17^{\text {th }}$ century. This remains a romanticized concept grounded in modern cultural stereotypes perpetuated in films, books and children's toys. The reality of $17^{\text {th }}$ century mercantile pirates was more complex in that they operated in an often ambiguous legal sphere, celebrated by the media and often tolerated - and sometimes even encouraged - by governments (Cordingly 2006).

Our use of the term within this paper is therefore based upon piracy as a symbolic concept, with a focus not on the label of "pirate" itself but on conceptualizing the behaviors that underlie it. Specifically, we suggest that the nature of entrepreneurship itself enables entrepreneurs to be the source of innovation and creative destruction (Anderson and Warren 2011). Piracy as a symbol is not about the fictionalized Hollywood representation of the pirate, but more as the way that piracy can be seen to represent a route to freedom. In this case the freedom sought is to challenge existing norms, escape from bureaucratic organizational forms and enable capitalism to evolve (Durand and Vergne 2013). In a conceptual sense the use of the term pirate can therefore be seen as part of the process of legitimating an activity that might otherwise be seen as illegitimate.

In a modern commercial context, direct association between piracy and innovation has been most publicly seen in the examples of "pirate" media, such as the growth in pirate radio stations (Johns 
2010a) and intellectual property piracy. Opportunities for piracy of intellectual property (IP) have arisen from the growth in information technology over the last three decades (Johns 2010b). Throughout the 1990s the primary focus was on software piracy (Sims et al. 1996), more recently expanding to include the widespread pirating of both music and video content through digital channels. Although research focuses upon the mechanisms by which "consumers" seek to partake in illegal activities (e.g. Liao et al. 2010), the question of IP piracy has itself become increasingly ethically contested. Whilst IP piracy remains illegal, it attracted a certain social acceptability that contrasted with the negative associations relating to the theft of physical goods (Vitell and Davis 1990). Thus, the movie industry refers to piracy as "copyright theft", recognizing that repeating the use of the term "pirate" runs the risk of inadvertently lending legitimacy to copyright infringers ${ }^{1}$. On the other hand, there has been debate over the extent to which the "pirates" have also been a force for innovation in an industry dominated by incumbents and high barriers to entry (McCourt and Burkhart 2003). How do we distinguish "copyright theft" from innovation (Gollin 2010)? For example, the form of subscription-based media consumption available in services like Spotify and Netflix was first introduced by services such as Napster, long accused of facilitating the pirating of music. Even within the software sector Microsoft founder, Bill Gates, acknowledged that software piracy could help establish the firm in emerging markets whilst minimizing the longer-term risk from lower cost competitors (Piller 2006). Core aspects of these trends have merged into "piracy" becoming a shorthand for innovation and, due to association with entrepreneurial activities, a popular concept among management consultants and business "gurus" who call upon managers to behave like pirates (Morgan 2004; Maddock and Viton 2011) or reflect upon the "Top 7 Management Secrets of Blackbeard the Pirate" (Wise 2010).

\footnotetext{
${ }^{1}$ Trade groups representing the entertainment industry typically use the phrase "copyright theft" in their naming. For example, the UK Federation Against Copyright Theft (FACT) or Irish National Federation Against Copyright Theft (INFACT). The software industry has adopted these naming guidelines with the Federation Against Software Theft (FAST).
} 
We suggest that the concept of piracy in management has emerged as a response to a perception that bureaucratic processes, including those created by industry level regulations and rules, have acted as a brake on innovation in industry. The use of the concept of the pirate is a way of adding legitimacy to behavior that is ethically contested in terms of legal or regulatory compliance. We now unpack the concept of piratical innovation at the level of the firm through the development of a conceptual model.

\section{Piratical Innovation and Labelling}

We propose piratical innovation as a firm level process enabling innovation by disrupting established regulatory norms. Piratical innovation can thus be seen as an attempt to shift institutional logics by generating regulatory discontinuities. In doing so, firms must also address a basic tension in that by disrupting these norms they also risk the generation of negative legitimacy judgments. The essential paradox of piratical innovation is in finding ways to mitigate these legitimacy judgments and minimize institutional barriers to growth. We suggest that piratical innovation is enacted through the use and manipulation of labels. Labelling theory in relation to the "outsider" and role of "the other" (Becker 1973) allows a view of piracy as a type of "avant-gardist deviance which generates two dynamics, either conformist or subversive" (Bureau 2014, p. 426). In this way piracy can be seen as conformist or subversive, or paradoxically both at the same time. The subversive dynamic also allows the pirate to succeed through challenging the status quo and thereby changing the rules. If this happens, pirates may no longer be labelled as deviants but instead be designated as creative, successful entrepreneurs. As such, labelling theory provides an effective theoretical device through which to understand the ways a firm can be designated both as piratical and as innovative, creative and successful (Bureau 2014). As values and entrepreneurial cultures change, so too do our definitions of pirate and piracy, and what is legitimate as an entrepreneurial approach (Pitz and Adler 2014; Roth 2014a; 2014b).

As a sociological theory, labelling theory is largely concerned with the role that authority, status and power play in the assignment of social identities (Ashforth and Humphrey 1995; 1997). The 
labelling process is arbitrary, socially constructed, dynamic, not tied to some underlying truth. Indeed, "the very act of labelling is dependent on memory and learning; the process of naming and labelling does not occur afresh each day - the stock of what can be named develops" (Chell 2007, p. 15). However, the focus of labelling theory is also on how the acts of labelling and giving definition to actors, actions and entities can facilitate control. As a result, organizations that can influence how labels are applied to a firm can also control the perceptions of legitimacy surrounding a firm. In other words, firms can mitigate against the impact of core audiences that seek to avoid organizations that are perceived to be undertaking acts that have been defined as deviant (Jonsson et al. 2009).

Although labelling theory is concerned with the social context in which meaning is constructed (Chell 2007), it is typically still understood as an individual level process, such as understanding how others label each other as, for example, "the other" or "outsiders" (Becker 1973). However, labels can also be applied at an organizational level, and the way organizations are understood by both internal and external stakeholders has been the subject of various streams of research on organizational image, identity or reputation. Labels can be understood as the mechanism through which these perceptions of organizations, whether from internal or external actors, can be communicated. In an organizational sense, labels provide a means through which to "distill a complex jumble of otherwise ambiguous and contradictory activities, pronouncements, and impressions into a simplified and relatively coherent portrait" (Ashforth and Humphrey 1997, p. 53). We suggest this definition has an important parallel with the nature of early stage entrepreneurship, in that small firms lacking legitimacy must find ways in which to project their organizational identity to stakeholders faced with clutter and ambiguity when trying to evaluate organizations that lack a tangible financial track record. Labels can therefore provide a way of providing clarity where there is ambiguity, an important role for small firms.

Studies into small firms have touched on the ways firms seek to influence the labels that they and others use to describe their firm. For example, entrepreneurs' stories and anecdotes are designed to create favorable interpretations of the firm's potential success (Lounsbury and Glynn 2001). Labels 
are often used as part of these stories, and in a wider context to help signal the potential future success of a firm. The pursuit of funding labels such as "unicorn" or popular industry labels such as "fintech" helps to position a firm as being on a successful trajectory. Even some aspects of entrepreneurial activity not associated with success can be managed with labels, "pivoting" being a label to describe a firm that is seeking to successfully reposition itself due to a failing business model. Because labels simplify, they provide clarity in an entrepreneurial environment often characterized by ambiguity.

The existence and use of organizational labels is not passive but can be understood as part of an active management strategy. Just as a great deal of effort goes into managing organizational image and reputation, so too can the labels used by organizations and their stakeholders. If firms can better control the labels that are used to describe them, then given the power and importance of labels, a competitive advantage can be formed. The forms of piratical innovation critiqued in this paper are, by their nature, formed around contested notions of labels. Indeed, the success of piratical innovation can be seen in entrepreneurs' ability to ensure that labels "stick" that might otherwise have been contested. Ashforth and Gibbs (1990) argue that where notions of appropriate labels are divergent between different stakeholder groups, then the outcome over which label becomes adopted in practice is determined by a form of labelling contest. Labelling contests differ from a process under which identity or reputation might be socially constructed through labels coalescing towards "a modal socially-validated view" (Ashforth and Humphrey 1997, p. 54). Rather, they are characterized by both power imbalances between stakeholders as well as imbalances in motivations and willingness to use such power (Ashforth and Humphrey 1997; Lawrence and Lorsch 1967). Understanding how small firms apply these processes is key to the application of successful labels, and piratical innovation itself.

We now put forward a conceptual model developed in order to explain how small firms are able to manipulate labels. This is a particularly challenging task for small firms given that power is a resource that such firms, by their nature, typically lack when compared to other stakeholders. In the context of the regulatory innovation provided by the model's framework, the power imbalances are 
particularly stark; small firms are not battling competitors but governments and the social and legal factors that underpin them. This model therefore seeks to explain the paradox of how small firms without access to power can manage to succeed in contests that require the use of power. Specifically, the framework suggests that labelling contests can be won through the skillful use of both substantive and symbolic actions. In this context, substantive actions relate to the activities which are necessary to enact piratical forms of innovation. These include strategic attitudes towards regulation and resource allocation. However, on their own these substantive actions are likely to attract negative labels, and thus negatively impact the legitimacy of the firm and their ability to grow.

The key to winning these labelling contests, and the key to piratical innovation, is the further use of symbolic actions that create dissonance between the source of power and the stakeholder using it. The use of symbolic actions, for example community embeddedness and blurring organizational boundaries, serves to alter the labels applied to a firm's activities. In doing so, this moderates negative legitimacy judgements.

\section{Piratical Innovation and Firm Growth: Research Propositions \& Conceptual Model}

\section{Substantive Actions and Legitimacy Judgments}

A principle mechanism through which piratical innovation enables growth is through challenging existing regulatory and political frameworks. The effectiveness of such approaches depends on the extent to which competitive advantage can be sustained. The sustainable competitive advantage that might be gained through manipulation of the regulatory or political environment could be limited as any advantage could be easily copied by competitors, as regulatory factors typically apply at an industry rather than firm level. Conversely, firms seeking to manage their organizational risk profiles are likely to be wary of such manipulations where they are perceived as risky, even when a competitor is undertaking them. When undertaking risky activities, a rational economic perspective might see firms seeking to underplay the risks involved. However, in the case of piratical innovation, 
we suggest that it is necessary for firms to emphasize risks, or even exaggerate them, with a view to influencing their competitors' risk judgements. To achieve this, they leave a number of risk signals that serve as pointers to competitors. For example, whilst the ride-sharing startup Uber has frequently faced regulatory hurdles its strategy through its initial growth phases was built upon "a reputation for riding roughshod over the objections of regulators, taxi drivers and politicians" (Hook 2016). This had the effect of widely signaling the regulatory conflicts that the firm was facing in the media.

Proposition $1 a$ : Signaling the strategic risk of piratical approaches dissuades competitors from copying these strategies.

However, simply ignoring rules and regulations wholesale - whatever the short-term benefit - brings financial and legal risks to firms. As such, the success of piratical innovation is not based upon ignoring regulation but, rather, seeking to subvert it. We suggest that a process of regulatory arbitrage is used to highlight inconsistencies or ambiguity present in regulatory processes that are operated at different levels, in different geographies or under competing regulatory frameworks. This leverages a characteristic of the regulatory state whereby regulatory pressure is increasingly being used as an alternative to taxation and spending as a means of maintaining state control (Majone 1997). Within this there are a growing range of actors with the ability to create regulations, including local, regional and national governments as well as trans-national bodies and trade groupings as well as more traditional regulatory bodies such as trade and professional groups. On top of this, there is the temporal dimension where regulations are typically implemented with a rear-view mirror in response to a failure, or perceived failure, of the market that needs regulating. This provides rich opportunities for organizations to leverage inconsistencies in regulatory frameworks and play-off differing regulatory actors against themselves. This can be done by highlighting inconsistencies in the regulations themselves, or by identifying ways in which regulations are no longer an appropriate fit for the regulatory environment in which they operate. For example, Uber and AirBnB both seek to leverage 
the differences in regulations governing their services at a city or state level as well as generating ambiguity over their relationship with service providers (Quattrone, et al. 2016). When faced with criticisms over the impact of short-term lettings on housing supply Airbnb has sought to develop direct relationships implying partnership with specific towns and cities to address such problems. This activity has the effect of creating doubt around the effectiveness of the regulations or rules and, on a local level, can call into doubt the legitimacy of the regulatory process itself.

Proposition 1b: By leveraging regulatory arbitrage through piratical innovation, unique firm level regulatory advantages can be created.

The third component of substantive management action is the allocation of available capital directly to firm growth. Firms have a choice as to when, and where, to apply available capital. If growth is sought, then one technique to indirectly achieve it applying capital to service or product development with the aim of develop a competitive advantage. However, with piratical approaches to innovation capital are directly applied to growth, for example by reducing prices, subsidizing supply chains or undertaking extensive promotional activity. Without the goal of pursuing firm growth, the strategy of piratical innovation could be considered too risky. As piratical innovation is a time-limited strategy for the acquisition of market share, firms must allocate capital in a way that enables them to grow as quickly as possible, so as to be the winner in a "winner takes all" market.

Proposition 1c: As piratical innovation is a time-limited activity, available capital is allocated to activities that directly enable firm growth.

When combined together, the use of substantive actions without any moderating factors can be considered as the pursuit of high-levels of growth in defiance of institutional norms. In turn, these 
actions generate risk as they are likely to result in negative labels being applied to a firm and, ultimately, more negative legitimacy judgments from external stakeholders.

\section{Symbolic Moderators as Symbolic Actions}

We suggest that the impact of negative labels are managed through the use of symbolic actions that moderate the formation of negative legitimacy judgments. Symbols have long played an important role in social and organizational life. In organizations, symbols influence the construction of sense, knowledge, and behavior of employees (Rafaeli and Worline 2000), whilst the internal symbolic context of an organization influence how external stakeholders perceive it (Hatch and Schultz 1997). More simply, a symbol can be understood as something which stands for something else. Whilst symbolic actions may typically be used to signal future aspirations of a firm, such as renting a small office in a prestigious building, the role of symbolic actions as a moderator has the effect of distracting or deflecting from substantive actions.

Symbolic actions have been suggested as being harmful to firms when symbols are perceived as being unrelated to the core focus or challenges facing a company (Walker and Wan 2012). However, their use has also been seen as being effective as a short-term way to address an issue without expending the kinds of resources required for a longer-term solution (Westphal and Zajac 1998). For example, firms may take symbolic measures to position themselves as appearing environmentally friendly without actually taking substantive actions, such as reducing waste or emissions. To be effective, symbolic moderators must help to generate doubt or create confusion over the relevant labels linked to substantive actions. Thus, in terms of a labelling contest the purpose is not simply to remove negative labels but also to create confusion about the appropriateness of the labels which are to be attached to substantive actions. When symbolic actions contradict those that are substantive, there is the potential for dissonance, which makes it more difficult for institutional actors to attribute specific labels and, in turn, for the legitimacy judgments which can be formed. 
We suggest three categories of symbolic moderators are used in influencing legitimacy judgments in this way. The first is community embeddedness, mimicking the classic piratical technique of appealing as standing-up for a particular community or communities against a regulatory power. Individuals pirating music or video claim to be members of communities in which their "customer" audience operates, whilst positioning legal and regulatory authorities as the "other". This approach has been adopted by a number of piratical firms seeking new ventures. Firms seeking to exploit network effects have attempted to label their own networks as communities mimicking the language of more open peer-to-peer based communities such as Wikipedia, Kiva or Kickstarter (Hamari et al. 2015). Uber describes its drivers as "partners" whilst Airbnb refers to both accommodation providers and customers as its "community". This provides firms pursuing piratical innovation with two advantages. Firstly, it gives a plausible and potentially defensible reason for the use of the types of regulatory arbitrage described previously. Secondly, it makes it more challenging for regulators to take action against the pirate as it also requires them, implicitly or explicitly, to take action against a community. When regulators depend on public acceptance, or even votes, to maintain their political legitimacy, taking these actions can be difficult.

Another symbolic moderator can be found through attempts to blur organizational boundaries. These include both the boundaries between the consumer and organization, by use of the language of co-creation, and those between the organization and various layers of employees. Just as firms seeking network effects rely on utilizing networks of customers, other networks within a firm's supplier chain are, arguably, even more important. For example, the growing use of independent contractors in a "gig economy" over permanent or direct employment. Firms seek to ensure that their brand is prominent on various service touch points, on apps, clothing or even vehicles. At the same time, they go to great lengths to argue that such labelling signals membership of a network rather than employment. Allocation of capital to growth has typically involved purchasing market share through, for example, subsidizing the cost of products consumed. This creates a difficulty in that many of these businesses 
are highly capital intensive. By encouraging the "network" to bear capital costs, be it cars (Uber), property (Airbnb), restaurant kitchens (Deliveroo) or other resources, capital is freed up to be applied to achieving customer growth. Whilst these individuals may be in some sense self-employed, they are not utilizing resources beyond their control in the traditional entrepreneurial sense, rather they are being encouraged to better utilize resources they would not normally be able to gain monetary value from. This creates confusion when legitimacy judgments are made as, where organizational boundaries are blurred, it can be difficult to determine where judgments over legitimacy must lie. Where supplier networks within the sharing economy have been found behaving or operating unethically, firms have been able to distance themselves from the activity. This ability to shift positionality can even enable firms to portray themselves as an arbitrator between different stakeholder groups.

Finally, a symbolic moderator can be seen in the way that legitimacy myths are created surrounding incumbent competitors' actions. Whilst "the other" in institutional theory is positioned as regulatory or government actors, the pirate seeks to refocus "the other" as their competitors. Where traditional forms of legitimation involve copying institutional traits used by competitors, with piratical innovation the focus is on seeking to create distance between the piratical innovator and existing firms. The role of the legitimacy myth is to call into doubt the legitimacy of existing firms' relationships with stakeholders. For example, Uber frequently adopts a strategy of positioning existing taxi drivers as operating as a quasi-monopoly by leveraging their close relationship to regulators and other political actors, with the result of higher prices and/or worse service (Rodionova 2016). Thus, by claiming the label of community embeddedness for itself, and seeking to deny this label to others in the same industry, dissonance can be created around which actor within an industry is behaving illegitimately.

Proposition 2: Symbolic moderators of piratical innovation, when combined with substantive actions, create dissonance that weakens other stakeholder labels and mitigates their impact upon the formation of legitimacy judgments. 
By preventing negative labels from being attributed to the firm because of substantive actions taken, symbolic actions can enable higher levels of firm growth. Effectively, through minimizing negative legitimacy judgments firms can grow more quickly despite any negative responses resulting from these actions.

Proposition 3: Legitimacy judgments that are formed following use of piratical innovation do not impede the rate of firm growth.

\section{A Conceptual Model of Piratical Innovation and Firm Growth.}

This process of piratical innovation resulting in firm growth, as reflected in the propositions, is illustrated in Figure 1. As shown in this diagram, piratical innovation involves a labelling contest where firm-generated labels compete with other stakeholder-generated labels in the determination of legitimacy judgments. We suggest that substantive actions associated with piratical innovation would, on their own, generate negative legitimacy judgments. However, firms can utilize a number of symbolic moderators to limit these judgements from forming, leaving space for more positive legitimacy judgments, and resultant firm growth.

\section{[Insert Figure 1 about here]}

Furthermore, Table 1 provides a number of examples of firms where piratical innovations have been identified, together with details of the evidence that underlines the use of this strategy. These examples are indicative but demonstrate the scope of application of piratical innovations.

[Insert Table 1 about here] 


\section{Risks and Responses to Piratical Innovations}

As outlined earlier, adopting piratical innovations can bring a number of risks to firms that can broadly be categorized into three types. Firstly, there is the question of continuing availability of capital throughout the growth phase. As the growth phase is typically characterized by a period of loss making, where there is insufficient capital to gain market share (van Stel et al. 2007), a firm can be left in a financially unsustainable position. For example, within firms seeking to build their business model around food delivery, there has been a high level of firm level failure, and a reluctance around investors to fund capital for such services (Satariano 2018). In the pursuit of winner takes all markets, whilst success may produce an absolute form of competitive advantage, so can failure.

Secondly, the dependence of piratical innovation upon regulatory arbitrage assumes that firms are able to navigate around regulatory issues and maintain their advantage during the growth phase. These regulations may relate to formal government level regulatory frameworks or industry level policies, regulations or "rules of the game". By their very nature these forms of arbitrage are based around contested boundaries and it may be difficult to correctly establish the limits of where arbitrage can successfully be applied. This is compounded by the ways in which the existence of regulatory disputes can be leveraged to signal risk. Perhaps the most public of these recent regulatory disputes is the way in which Uber is finding itself locked out of markets through a failure to effectively navigate the shifting regulatory landscape. For example, its unwillingness to follow licensing guidelines for drivers, on the grounds that they are not employees, has led to the potential banning or restrictions of the service in many cities, not least London which is one of the most important markets (Ram 2017).

Thirdly, there is the risk of damaging corporate reputations that firms may face undertaking these strategies, and the potential impact these may have upon a firm. Thus, Uber is also suffering reputational risk when accused in the media in such statements as: "Another day, another revelation of an ethically questionable business practice by Uber" (Shu 2017). Successfully managing corporate reputations is identified as important in the context of an increasingly complex regulatory environment 
in which firms operate (Power et al. 2009). However, even when firms are able to use such piratical strategies to enable growth, there may be a cost to being piratical in terms of the firm's broader reputation if they cannot successfully manage legitimacy judgements. Just as costs to a firm in terms of a failure to have sufficient capital to achieve sustainability and profitability can be absolute, so too can cost of failure to mitigate against negative reputations when piratical behaviour must be defended.

Ultimately, the limitations of piratical approaches to innovation are embedded in the risks we have discussed in their function as a means to an end, rather than an end in itself. These piratical approaches are effective to the extent to which they enable levels of growth that allow a firm to achieve dominance of a "winner takes all" market and exert control in areas such as pricing or product development. The risks of a failure to "win" can leave a firm in a precarious situation, both in terms of profitability and relationships with stakeholders.

Secondary to the questions around the risks of adoption of piratical approaches are the risks for those small firms which must compete in markets where the competitive landscape is being shifted through the adoption piratical approaches. Two binary responses exist. The first is mimetic, to copy the piratical innovation themselves. Adoption of such strategies is paradoxical given that the piratical innovation is embedded in strategies that run counter to traditional approaches to building legitimacy through isomorphism (Deephouse 1996). Where capital is available this may be the most directly disruptive mechanism to maintain market share, but is also associated with high levels of risk, particularly if adopted reactively. The corollary of this is to take a passive approach and, given the risks associated with piratical strategies where multiple firms in the same market adopt such strategies (Satariano 2018), to wait for the "pirate" to fail. For firms that lack capital and/or the ability to apply capital expenditure to activities generating growth, this may be the only option available to managers.

Alternatively, a direct response could be enabled by challenging the forms of symbolic moderators featured in the model suggested in this paper. In other words, rather than direct competition, this would be to take actions that limit a firm's ability to leverage piratical innovations. 
This can include exerting their own community embeddedness, and questioning the legitimacy of the pirates' link with stakeholders, whilst seeking to undermine any legitimacy myths that are created. Essentially, this form of response is not about the adoption piratical innovations directly but to seek to prevent the firm exploiting piratical strategies from winning labelling contests.

\section{Discussion and Conclusion}

Leeson (2009) argues, in the tradition of other scholars of deviance, and the labelling of certain organizational forms as deviant (e.g. Becker 1968; Fiorentini and Peltzman 1995), that the drive for economic self-interest can create unintended consequences of social benefit. Thus, Adam Smith's invisible hand, where lawful self-interest creates positive outcomes for society, is replaced for pirates by an "invisible hook" where illegitimate or criminal self-interest drives the creation of social value. Yet piratical innovation is not driven directly or indirectly by such illegitimate or criminal self-interest. Rather, firms are adopting an alternative form of enterprise and innovation, leveraging outsider and anti-establishment identities to reorder institutional logics to their advantage. In the broader macroeconomic context where a low interest rate environment has created a surplus of growth capital, the use of piratical techniques has increased because of the shifts in financial incentives towards rewarding short-term growth amongst new ventures.

The risks of adopting piratical strategies are touched upon in this paper. Firstly, subversion of regulatory legitimacy has its limits. A core of piratical legitimacy is the use of regulatory arbitrage, a process by its very nature cannot be continued forever. The pursuit of an arbitrage opportunity will eventually eliminate it, in this case through the development of more effective regulation. Many of the growth strategies outlined in this paper are based upon loopholes or ambiguities in the regulatory frameworks that pervade modern economies. If these loopholes are closed, then firms are faced with a choice of edging closer to unethical, and potentially illegal, behavior or finding other ways through which to achieve growth. However, this leads directly to a second question of the economic 
sustainability of such practices. The pursuit of piratical innovation as a short-cut to growth raises the question of what happens when the destination is reached. Adapting the question posed by Birch (1979) to the modern day: When unicorns grow up do they become elephants or gazelles? By pursuing growth innovations (Birch et al. 1995; Henrekson and Johansson 2009) that embed illegitimacy within a business model, the question arises as to how well-positioned firms will be able to achieve operational success when the opportunities for growth slow. Firms that have sought to position themselves as victors in winner takes all markets must recognize the need to adopt a new strategic direction when they have 'won'. The financial rationale for investing in such markets is that a dominant firm within a market can leverage network effects to implement a monopolistic position. An ability to negotiate a regulatory context might be seen as an advantage when operating in a monopolistic environment, as it could be argued that a firm with the skills to manage the challenges of regulatory arbitrage can also address the problems of monopolistic regulation. Absence of further arbitrage opportunities can be overcome through the benefits of scale.

When in a monopolistic position, the need to conform to regulations can be a barrier to entry for new firms. It has been suggested that firms which can "win" in such markets will become networked-monopolies (Balaram 2016), where monopolistic power is not vested in resources controlled by the firm, but in control of both the supplier and customer networks. Yet, it remains unclear whether monopoly power will lie with the firm or the "crowd" - the supplier and customer networks on which the firm depends (Foster et al. 2011). Just as a firm within a traditional monopoly can use its power to make pricing or policy decisions that favour itself, so the networks might also use such power to the detriment of the firm. In the case of Uber or Lyft, the power that both drivers and customers have to shop around for the financial model most beneficial for them personally could turn a "winner takes all" market into a "loser takes nothing" situation. There is emerging evidence that the network power of consumers is leaving firms with difficulty in raising prices and therefore with challenges in finding an appropriate financial model even when they scale (Manjoo 2016). 
Lastly, there are the broader ethical considerations. Discussion of unethical behavior in firms often centers on the social and economic costs of their actions in terms of the products and services they provide. It is not unusual or remarkable, if not always desirable, for firms to be seen to lobby law makers and legislators to minimize the impacts of unfavorable legislation. However, there is a key difference between this form of relatively everyday corporate activity and that associated with piratical innovation. Specifically, most firms still seek regulatory legitimacy, but they attempt to influence the manner in which the regulations are developed. By contrast, the types of innovation described in this paper are built around celebrating non-compliance with regulatory processes or norms.

In conclusion, addressing a deficit of legitimacy is an important challenge facing firms wishing to grow. It also presents a paradox for firms lacking resources but still seeking to grow, as the pursuit of legitimacy requires firms to adopt some of the norms of existing firms which, in turn, can harm their potential for innovation. This can be partly resolved by allocating capital to the more effective development of innovations. However, this in turn reduces capital available to be allocated to growth. In the context of firms seeking extreme levels of growth, we argue that legitimacy should not be characterized as a linear construct, but rather it represents a series of challenges and trade-offs with embedded risks. The approaches to piratical innovation highlighted here present one potential route through which to resolve these paradoxes. Whilst piratical approaches to business are not new, they have been adopted and adapted by many firms in recent years as a response to the growing supply of growth capital. Given an excess supply of capital, piratical innovation provides a mechanism through which to increase the rate at which capital can be usefully injected into a business to enable it to grow. The unresolved question is whether the networked power of customers and suppliers that piratical innovation leverages can prevent a firm from building a sustainable advantage once it has "won" a market. 


\section{References}

Aldrich, H., and E. Auster (1986). 'Even Dwarfs Started Small: Liabilities of Age and Size and Their Strategic Implications,' Research in Organizational Behavior 8, 165-198.

Anderson, A., and L. Warren (2011). 'The Entrepreneur as Hero and Jester: Enacting the Entrepreneurial Discourse,' International Small Business Journal, 29(6), 589-609.

Ashforth, B., and B. Gibbs (1990). 'The Double-edge of Organizational Legitimation,' Organization Science, 1, 177-194.

Ashforth, B., and R. Humphrey (1995). 'Labeling Processes in the Organization,' Research in Organizational Behavior, 17, 413-61.

Ashforth, B., and R. Humphrey (1997). 'The Ubiquity and Potency of Labeling in Organizations,' Organization Science, 8, 43-58.

Balaram, B. (2016). Fair Share: Reclaiming Power in the Sharing Economy. London: RSA Action and Research Centre.

Becker, G. (1968). 'Crime and Punishment: An Economic Approach,' Journal of Political Economy, $76,169-217$.

Becker, H. S. (1973). Outsiders: Studies in the Sociology of Deviance. New York: Free Press.

Birch, D. L. (1979). The Job Generation Process. Cambridge, MA: MIT Program on Neighborhood and Regional Change, Massachusetts Institute of Technology.

Birch, D. L., A. Haggerty, and W. Parsons (1995). Who's Creating Jobs? Boston: Cognetics Inc.

Bruederl, J. and R. Schussler (1990). 'Organizational Mortality: The Liabilities of Newness and Adolescence,' Administrative Science Quarterly, 35, 530.

Bureau, S. (2014). 'Piracy as an Avant-gardist Deviance: How do Entrepreneurial Pirates Contribute to the Wealth or Misery of Nations?' International Journal of Entrepreneurship and Small Business, 22(4), 426-438.

Chell, E. (2007). 'Social Enterprise and Entrepreneurship: Towards a Convergent Theory of the 
Entrepreneurial Process,' International Small Business Journal, 25, 5-26.

Coad, A. J. Frankish, R. G. and D. J. Storey (2013). 'Growth paths and survival chances: An application of Gambler's Ruin theory'. Journal of Business Venturing, 28(5), 615-632.

Chaboud, M. C. (2014). 'Pirates Never Sail Alone: Exploring the Mechanics of Social Entrepreneurship Involved in Software Piracy,' International Journal of Entrepreneurship and Small Business, 22(4), 519-536.

Churchill, N. C., and V. L. Lewis (1983). 'The Five Stages of Small Business Growth,' Harvard Business Review, 61(3), 30-39.

Cordingly, D. (2006). Under the Black Flag. New York: Random House.

Davies, A. (2017). 'Uber May be Aflame, but its Self-driving Cars are Getting Good,' Wired, $28^{\text {th }}$ Dec. https://www.wired.com/story/uber-self-driving-cars-pittsburgh/ Accessed $21^{\text {st }}$ January 2018.

De Clercq, D., and M. Voronov (2009). 'Toward a Practice Perspective of Entrepreneurship: Entrepreneurial Legitimacy as Habitus,' International Small Business Journal 27(4), 395-419.

Deephouse, D. (1996). 'Does Isomorphism Legitimate?' Academy of Management Journal, 39(4), 1024-1039.

Deephouse, D. (1999.) 'To be Different, or to be the Same? It's a Question (and Theory) of Strategic Balance,' Strategic Management Journal, 20, 147-166.

Deephouse, D. L., and M. C. Suchman (2008). 'Legitimacy in Organizational Institutionalism,' in The Sage Handbook of Organizational Institutionalism. Ed. R. Greenwood, C. Oliver, K. Sahlin, and R. Suddaby. Thousand Oaks, CA: Sage, 49-77.

Durand, R., and J. Vergne (2013). The Pirate Organization: Lessons from the Fringes of Capitalism. Boston: Harvard Business Press.

Elsbach, K. (2003). Organizational Perception Management. London: Routledge.

Elsbach, K., and R. Sutton (1992). ‘Acquiring Organizational Legitimacy through Illegitimate Actions: 
A Marriage of Institutional and Impression Management Theories,' Academy of Management Journal, 35, 699-738.

Fiorentini, G., and S. Peltzman (1995). 'Introduction,' in The Economics of Organised Crime. Ed. G. Fiorentini, and S. Peltzman. Cambridge: Cambridge University Press and CEPR.

Foster, J. B., R. W. McChesney, and R. J. Jonna (2011). 'Monopoly and Competition in Twenty-first Century Capitalism,' Monthly Review, 62(11), 1-39.

Garud, R., H. Schildt, and T. Lant (2014). 'Entrepreneurial Storytelling, Future Expectations, and the Paradox of Legitimacy,' Organization Science 25, 1479-1492.

Goodwin, T. (2017). 'The Battle Is For The Customer Interface,' Techcrunch $3^{\mathrm{r}}$ March. https://techcrunch.com/2015/03/03/in-the-age-of-disintermediation-the-battle-is-all-for-thecustomer-interface/ Accessed $21^{\text {st }}$ January 2018.

Gollin, M. (2010) ‘Theft or Innovation?’ Nature, 463(7284), 1022-1023.

Hansen, B., and R. Hamilton (2011). 'Factors Distinguishing Small Firm Growers and Non-growers,' International Small Business Journal, 29(3), 278-294.

Hamari, J., M. Sjöklint, and A. Ukkonen (2015). 'The Sharing Economy: Why People Participate in Collaborative Consumption,' Journal of the Association for Information Science and Technology, 67(9), 2047-2059.

Hatch, M., and M. Schultz (1997). 'Relations Between Organizational Culture, Identity and Image,' European Journal of Marketing, 31, 356-365.

Henrekson, M., and D. Johansson (2009). 'Gazelles as Job Creators - a Survey and Interpretation of the Evidence,' Small Business Economics, 35, 227-244

Hertzfeld, A. (1983). Pirate Flag http://www.folklore.org/StoryView.py?story=Pirate_Flag.txt Accessed $3^{\text {rd }}$ December 2017.

Hook, L. (2016). 'Uber Technologies: Uber Looks to Set a Different Route with Regulators,' 
Financial Times $5^{\text {th }}$ May https://www.ft.com/content/d8ac7e70-11ce-11e6-839f2922947098f0 Accessed 28 ${ }^{\text {th }}$ December 2017.

Hudson, B., and G. Okhuysen (2009). 'Not With a Ten-foot Pole: Core Stigma, Stigma Transfer, and Improbable Persistence of Men's Bathhouses,' Organization Science, 20, 134-153.

Jemielniak, D. (2014). Common Knowledge? An Ethnography of Wikipedia. Stanford: Stanford University Press.

Johns, A. (2010a). Death of a Pirate: British Pirate Radio and the Making of the Information Age. New York: Norton.

Johns, A. (2010b). Piracy: The Intellectual Property Wars from Gutenberg to Gates. Chicago: University of Chicago Press.

Jonsson, S., H. Greve., and T. Fujiwara-Greve (2009). 'Undeserved Loss: The Spread of Legitimacy Loss to Innocent Organizations in Response to Reported Corporate Deviance,' Administrative Science Quarterly, 54, 195-228.

Kaivo-oja, J. (2014). 'Three Theoretical Approaches to Pirate Entrepreneurship: Towards Future Studies of Pirate Entrepreneurship,' International Journal of Entrepreneurship and Small Business, 22(4), 449-465.

Kirchhoff, B. A., and B. D. Phillips (1988). The effect of firm formation and growth on job creation in the United States. Journal of Business Venturing, 3(4), 261-272.

Klepper, S. (2002). 'The Capabilities of New Firms and the Evolution of the US Automobile Industry,' Industrial and Corporate Change, 11, 645-666.

Lawrence, P., and J. Lorsch (1967). 'Differentiation and Integration in Complex Organizations', Administrative Science Quarterly, 12(1), 1-47.

Lechner, C., B. Soppe, and M. Dowling (2016). 'Vertical Coopetition and the Sales Growth of Young and Small Firms,' Journal of Small Business Management, 54, 67-84.

Leeson, P. (2009). The Secrets of Pirate Management. Princeton: Princeton University Press. 
Liao, C., H. Lin, and Y. Liu (2010). 'Predicting the Use of Pirated Software: A Contingency Model Integrating Perceived Risk with the Theory of Planned Behavior,' Journal of Business Ethics, $91,237-252$.

Lounsbury, M. and M. Glynn (2001). 'Cultural Entrepreneurship: Stories, Legitimacy, and the Acquisition of Resources,' Strategic Management Journal, 22(6-7), 545-564

Maddock, G., and R. Viton (2011). 'Plunder your Way to Innovation,' Businessweek $18^{\text {th }}$ January. http://www.businessweek.com/managing/content/jan2011/ca20110118_409747.htm Accessed 6th November 2017.

Majone, G. (1997). 'From the Positive to the Regulatory State: Causes and Consequences of Changes in the Mode of Governance,' Journal of Public Policy, 17(2), 139.

Malik, O. (2015). 'In Silicon Valley Now, it's Almost Always Winner Takes All,' The New Yorker. 30 ${ }^{\text {th }}$ December. http://www.newyorker.com/tech/elements/in-silicon-valley-now-its-almostalways-winner-takes-all Accessed $13^{\text {th }}$ November 2015.

Manjoo, F. (2016). 'The Uber Model, it Turns Out, Doesn't Translate,' New York Times. 23 ${ }^{\text {rd }}$ March. http://www.nytimes.com/2016/03/24/technology/the-uber-model-it-turns-out-doesnttranslate.html? r=0 Accessed $17^{\text {th }}$ December 2017.

Manyika, J., Lund, S., Bughin, J., Robinson, K., Mischke, J., and Mahajan, D (2016). 'Independent Work: Choice, Necessity, and the Gig Economy', McKinsey Global Institute, October, https://www.mckinsey.com/global-themes/employment-and-growth/independent-work-choicenecessity-and-the-gig-economy Accessed 2nd February 2018.

McCourt, T., and P. Burkart (2003). 'When Creators, Corporations and Consumers Collide: Napster and the Development of Online Music Distribution,' Media, Culture \& Society, 25, 333-350.

Mchawrab, S. (2016). 'M\&A in the High Tech Industry: Value and Valuation,' Strategic Direction, $32(6), 12-14$.

Merz, G. R., P. B. Weber, and V. B. Laetz (1994). 'Linking Small Business Management with 
Entrepreneurial Growth,' Journal of Small Business Management, 32(4), 48-60.

Mikhalkina, T. and L. Cabantous (2015) 'Business Model Innovation: How Iconic Business Models Emerge,' in Business Models and Modelling: Volume 33: Advances in Strategic Management. Ed. C. Baden-Fulle and V. Mangematin. Emerald Press, 59-95.

Morgan, A. (2004). The Pirate Inside. Chichester, England: John Wiley \& Sons.

Muzyka, D., S. Birley, and B. Leleux (1996). 'Trade-offs in the Investment Decisions of European Venture Capitalists,' Journal of Business Venturing, 11, 273-287.

Pfarrer, M., K. Decelles, K. Smith, and M. Taylor (2008). 'After the Fall: Reintegrating the Corrupt Organization,' Academy of Management Review, 33, 730-749.

Piller, C. (2006). 'How Piracy Opens Doors for Windows,' Los Angeles Times. $9^{\text {th }}$ April. http://msl1.mit.edu/furdlog/docs/latimes/2006-04-09_latimes_piracy_or_promotion.pdf Accessed $10^{\text {th }}$ December 2017.

Pitz, T., and T. Adler (2014). 'Entrepreneurial Piracy Through Strategic Deception: The 'Make, Buy, or Steal' Decision,' International Journal of Entrepreneurship and Small Business, 22(4), $466-481$.

Power, M., T. Scheytt, K. Soin, and K. Sahlin (2009). 'Reputational Risk as a Logic of Organizing in Late Modernity,' Organization Studies, 30(2-3), 301-324.

Quattrone, G., D. Proserpio, D. Quercia, L. Capra, and M. Musolesi (2016). 'Who Benefits from the "Sharing" Economy of Airbnb?' in Proceedings of the 25th International Conference on World Wide Web, April 11-15, Montreal, Canada. http://doi.org/10.1145/2872427.2874815. Geneva, Switzerland: International World Wide Web Conferences Steering Committee, 1385-1394.

Rafaeli, A. and M. Worline (2000). 'Symbols in Organizational Culture,' in Handbook of Organizational Culture and Climate. Ed. N. Ashkanasy, C. Wilderom, and M. Peterson London: Sage Publications, 71-84.

Ram, A. (2017). 'Uber London Licence Appeal Set for April at Earliest,' Financial Times $11^{\text {th }}$ Dec. 
https://www.ft.com/content/73f4467b-94f6-3caf-a2eb-4fddb73de6cd Accessed $21^{\text {st }}$ January 2018.

Rasmussen, C., G. Ladegård, and S. Korhonen-Sande (2016). 'Growth Intentions and Board Composition in High-Growth Firms,' Journal of Small Business Management. doi:10.1111/jsbm.12307

Reisenger, D. (2016). 'Why Apple is Flying a Pirate Flag Over its HQ,' Fortune. $1^{\text {st }}$ April. http://fortune.com/2016/04/01/apple-pirate-flag/ Accessed 28 ${ }^{\text {th }}$ December 2017.

Reuber, A. and E. Fischer (2010). 'Organizations Behaving Badly: When are Discreditable Actions Likely to Damage Organizational Reputation?' Journal of Business Ethics, 93(1), 39-50. Rodionova, Z. (2016). 'Uber Criticises Sadiq Khan for Favouring London Black Cabs,' The Independent. $13^{\text {th }}$ September. http://www.independent.co.uk/news/business/news/uber-sadiqkhan-black-cab-london-mayor-support-criticism-a7253261.html Accessed $17^{\text {th }}$ December 2017.

Roth, S. (2014a). 'The Eye-patch of the Beholder: Introduction to Entrepreneurship and Piracy,' International Journal of Entrepreneurship and Small Business, 22(4), 399-407.

Roth, S. (2014b). 'Booties, Bounties, Business Models: A Map to the Next Red Oceans,' International Journal of Entrepreneurship and Small Business, 22(4), 439-448.

Satariano, A. (2018). 'Deliveroo Takes a Kitchen-Sink Approach to Food Apps,' Bloomberg Businessweek $15^{\text {th }}$ January. https://www.bloomberg.com/news/articles/2018-01-15/deliverootakes-a-kitchen-sink-approach-to-food-apps Accessed 21 $1^{\text {st }}$ January 2018.

Schilling, M. (2002). 'Technology Success and Failure in Winner-take-all Markets: The Impact of Learning Orientation, Timing and Network Externalities,' Academy of Management Journal, 45, 387-398.

Shu, C. (2017). 'Uber Reportedly Tracked Lyft Drivers Using a Secret Software Program Named 
'Hell',' Techcrunch, 12 $2^{\text {th }}$ April. https://techcrunch.com/2017/04/12/hell-o-uber/ Accessed 21st January 2018.

Sims, R., H. Cheng, and H. Teegen (1996). 'Toward a Profile of Student Software Piraters,' Journal of Business Ethics, 15, 839-849.

Smith, D. C. (1980). 'Paragons, Pariahs, and Pirates: A Spectrum-based Theory of Enterprise,' Crime \& Delinquency, 26(3), 358-386.

Stern, R., J. Pfeffer and G. Salancik (1979). 'The External Control of Organizations: A Resource Dependence Perspective,' Contemporary Sociology, 8, 612.

Stinchcombe, A. L. (1965). 'Organizations and Social Structure,' in Handbook of Organizations. Ed. J. March. Chicago: Rand McNally, 153-193.

Storey, D. J., and F. Greene (2010). Small Business and Entrepreneurship. Essex: Pearson Education. Stringfellow, L., E. Shaw, and M. Maclean (2013). ‘Apostasy Versus Legitimacy: Relational Dynamics and Routes to Resource Acquisition in Entrepreneurial Ventures,' International Small Business Journal, 32(5), 571-592.

Suchman, M. (1995). 'Managing Legitimacy: Strategic and Institutional Approaches,' The Academy of Management Review, 20, 571.

Tan, J., Y. Shao, and W. Li (2013). 'To be Different, or to be the Same? An Exploratory Study of Isomorphism in the Cluster,' Journal of Business Venturing, 28, 83-97.

Tomczyk, D., J. Lee, and E. Winslow (2013). 'Entrepreneurs' Personal Values, Compensation, and High Growth Firm Performance,' Journal of Small Business Management, 51, 66-82.

Walker, K., and F. Wan (2012). 'The Harm of Symbolic Actions and Green-washing: Corporate Actions and Communications on Environmental Performance and Their Financial Implications,' Journal of Business Ethics, 109, 227-242.

Westphal, J. and E. Zajac (1998). 'The Symbolic Management of Stockholders: Corporate Governance Reforms and Shareholder Reactions,' Administrative Science Quarterly, 43, 127-153. 
Wise, J. (2010). 'Top 7 Management Secrets of Blackbeard the Pirate,' Psychology Today. $2^{\text {nd }}$ April. https://www.psychologytoday.com/blog/extreme-fear/201004/top-7-management-secretsblackbeard-the-pirate Accessed $20^{\text {th }}$ January 2017.

Wright, M., and I. Stigliani (2013). 'Entrepreneurship and growth,' International Small Business Journal, 31(1), 3-22.

van Stel, A., D. J. Storey and A. R. Thurik (2007). 'The Effect of Business Regulations on Nascent and Young Business Entrepreneurship,' Small Business Economics, 28(2-3), 171-186.

Vergne, J. (2012). 'Stigmatized Categories and Public Disapproval of Organizations: A MixedMethods Study of the Global Arms Iindustry, 1996-2007,' Academy of Management Journal, 55(5), 1027-1052.

Vitell, S., and D. Davis (1990). 'The Relationship Between Ethics and Job Satisfaction: An Empirical Investigation,' Journal of Business Ethics, 9, 489-494.

Zimmerman, M., and G. Zeitz (2002). 'Beyond Survival: Achieving New Venture Growth by Building Legitimacy,' Academy of Management Review, 27, 414.

Zott, C., and Huy, Q. (2007). 'How Entrepreneurs Use Symbolic Management to Acquire Resources,' Administrative Science Quarterly 52, 70-105.

Zuckerman, E. (1999). 'The Categorical Imperative: Securities Analysts and the Illegitimacy Discount,' American Journal of Sociology, 104, 1398-1438. 
Figure 1.

Conceptual Model of Piratical Innovation Through Labelling Contests

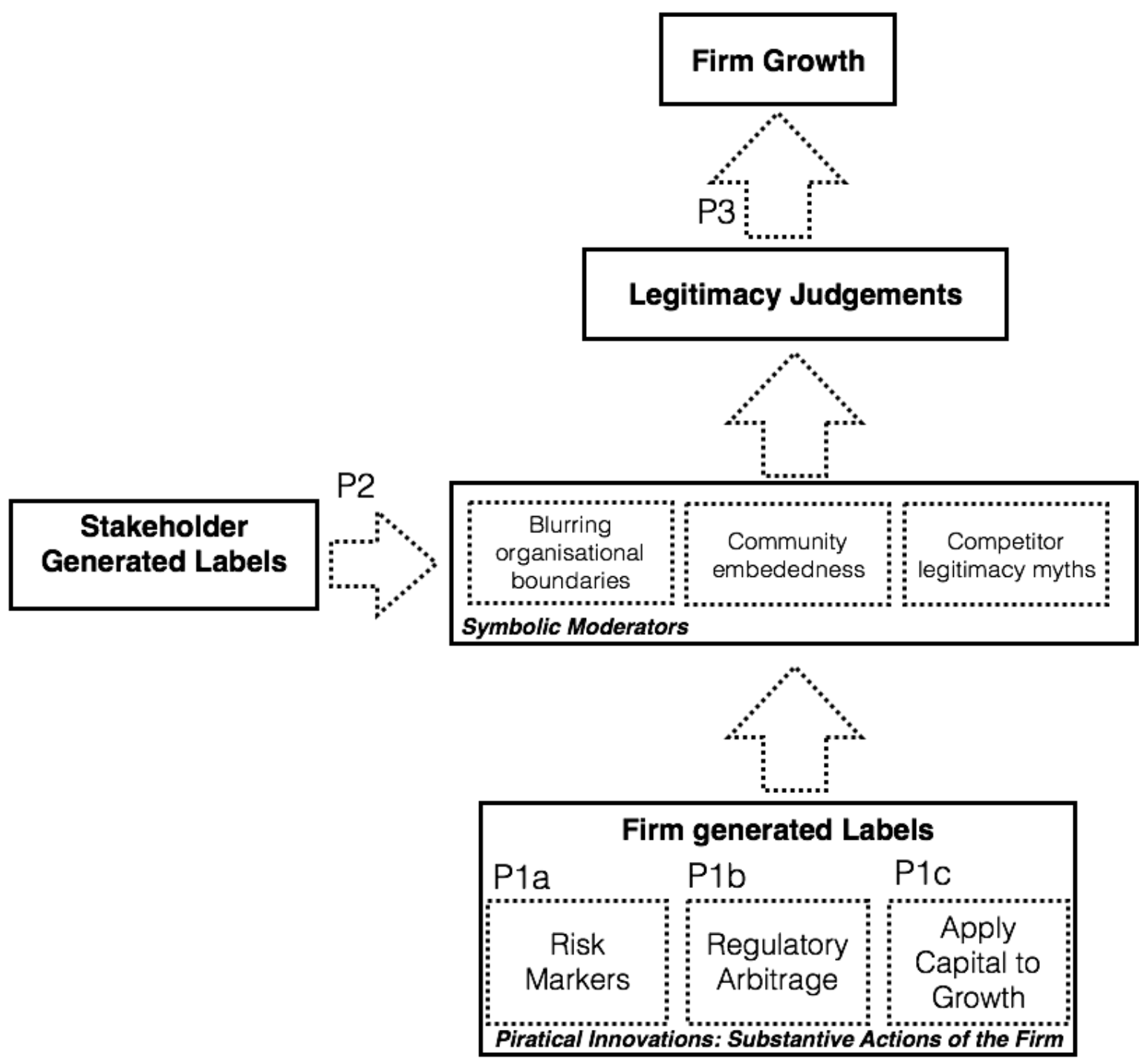


Table 1.

\section{Examples of Piratical Innovation}

\begin{tabular}{|c|c|c|c|c|}
\hline \multirow[t]{2}{*}{ Firm Name } & \multirow{2}{*}{$\begin{array}{l}\text { Firm } \\
\text { Network } \\
\text { Size } \\
\end{array}$} & \multicolumn{3}{|c|}{ Evidence of Piratical Innovations } \\
\hline & & Risk signals & Regulatory Arbitrage & $\begin{array}{l}\text { Applying capital } \\
\text { to growth }\end{array}$ \\
\hline $\begin{array}{l}\text { Uber } \\
\text { Personal } \\
\text { Transportation, } \\
\text { Taxi Services, } \\
\text { Food Delivery }\end{array}$ & $\begin{array}{l}>2 \text { million } \\
\text { drivers } \\
\text { worldwide }\end{array}$ & $\begin{array}{l}\text { Public battles } \\
\text { with } \\
\text { regulators \& } \\
\text { authorities }\end{array}$ & $\begin{array}{l}\text { Exploiting ambiguity in } \\
\text { regulations } \\
\text { surrounding what } \\
\text { counts as a taxi firm. }\end{array}$ & $\begin{array}{l}\text { Transferring } \\
\text { capital and } \\
\text { operational } \\
\text { costs of } \\
\text { vehicles to } \\
\text { drivers. }\end{array}$ \\
\hline $\begin{array}{l}\text { AirBnB } \\
\text { Lodging } \\
\text { Marketplace }\end{array}$ & $\begin{array}{l}>3 \text { million } \\
\text { lodging } \\
\text { locations }\end{array}$ & $\begin{array}{l}\text { Public battles } \\
\text { with } \\
\text { regulators \& } \\
\text { authorities }\end{array}$ & $\begin{array}{l}\text { Facilitating the use of } \\
\text { residential lettings for } \\
\text { commercial lets. }\end{array}$ & $\begin{array}{l}\text { Large scale } \\
\text { advertising } \\
\text { campaigns }\end{array}$ \\
\hline $\begin{array}{l}\text { Deliveroo } \\
\text { Food ordering } \\
\text { \& delivering }\end{array}$ & $\begin{array}{l}>20,000 \\
\text { delivery } \\
\text { drivers }\end{array}$ & $\begin{array}{l}\text { Public battles } \\
\text { with delivery } \\
\text { drivers / } \\
\text { riders over } \\
\text { employment } \\
\text { rights. }\end{array}$ & $\begin{array}{l}\text { Building large } \\
\text { 'branded' delivery } \\
\text { network whilst } \\
\text { maintaining } \\
\text { independent } \\
\text { contractor mode. }\end{array}$ & $\begin{array}{l}\text { Running } \\
\text { delivery at a } \\
\text { loss. }\end{array}$ \\
\hline $\begin{array}{l}\text { Turo } \\
\text { Peer-to-peer } \\
\text { car sharing }\end{array}$ & $\begin{array}{l}2,500 \text { cities } \\
\text { and } 300 \\
\text { airports }\end{array}$ & $\begin{array}{l}\text { Public battles } \\
\text { with } \\
\text { insurance } \\
\text { companies }\end{array}$ & $\begin{array}{l}\text { Attempting to work } \\
\text { around traditional } \\
\text { insurance models via } \\
\text { facilitating peer-to- } \\
\text { peer car sharing. }\end{array}$ & Car Insurance \\
\hline $\begin{array}{l}\text { MoviePass } \\
\text { Cinema } \\
\text { subscription } \\
\text { service }\end{array}$ & $\begin{array}{l}>1 \text { million } \\
\text { subscribers } \\
\text { in US }\end{array}$ & $\begin{array}{l}\text { Public } \\
\text { disagreement } \\
\text { with main } \\
\text { cinema chain } \\
\text { over access }\end{array}$ & $\begin{array}{l}\text { Offering subscription } \\
\text { service to filmgoers, } \\
\text { bypassing cinemas by } \\
\text { using technology to } \\
\text { acquire technology } \\
\text { without permission of } \\
\text { key stakeholder. }\end{array}$ & $\begin{array}{l}\text { Running core } \\
\text { service at loss } \\
\text { to build up } \\
\text { market share. }\end{array}$ \\
\hline
\end{tabular}

